DOI: 10.2478/pcssr-2013-0006

\title{
Sport and Recreation Grounds: Urban Society Expectations
}

Authors' contribution:

A) conception and design of the study

B) acquisition of data

C) analysis and interpretation of data

D) manuscript preparation

E) obtaining funding

\section{Anna Pawlikowska-Piechotka ${ }^{\text {A-E }}$, Karolina Sawicka ${ }^{\text {BCE }}$}

Josef Pilsudski University of Physical Education in Warsaw

ABSTRACT

Recently, changes to our pace of living and to our quality of life (including demands of our leisure possibilities) have been rapid. We now expect higher standards of living filled with goods, services, and recreation activities unimaginable some decades ago. In the last two decades, there have been massive changes in work, communication, and travel resulting in what could be described as "leisure revolution." The opportunities have increased in terms of both the time available and the variety of ways in which we can spend this time. Several aspects of physical exercise benefits are well recognized: we know that active recreation is especially stimulating and rewarding and that it helps to achieve sharper mental awareness and heightened consciousness. To be able to enjoy everyday outdoor active recreation and sports (netball, badminton, etc.), there has to be a network of recreation grounds and a supply of facilities that respond to the needs and expectations of society.

The study of contemporary trends of leisure provision could be an essential spatial planning tool when contemporary housing estates functional programs are considered. Our research study (conducted on the basis of grants ds-114 and ds-144 JP UPE in Warsaw; 2008-2012, supported by the Ministry of Science and Higher Education) aimed to provide information on present trends in the area of active recreation that could impinge on leisure facilities expected at urban housing estates (outdoor recreation grounds).

KEYWORDS $\quad$ sport and recreation grounds, urban society, healthy lifestyle

“Sport not as an aim in itself but always as a means of physical education” (Zygmunt Gilewicz) ${ }^{1}$

\section{Introduction}

The relationship between active lifestyle and environment is very complicated. People's participation in sports and everyday physical activities is influenced by a number of various factors such as culture, family tradition, sex, ability, time, level of education, occupation, income, motivation, and, last but not least, by the built and natural environment they live in. However, we cannot diminish personal factors, such as age or

\footnotetext{
${ }^{1}$ This principle was formulated by Professor Zygmunt Gilewicz (1881-1960), a physician and specialist in physical education. In 1931-1938 he was a Director of the Central Institute of Physical Education (CIPE) in Warsaw and Vice Chancellor of Academy of Physical Education after World War II. Nota bene CIPE was the first official name of Josef Pilsudski University of Physical Education in Warsaw.
} 
tradition, in one who has been brought up with - which strongly shapes the style of living - appropriate outdoor recreation space in surrounding neighborhoods with good and solid facilities, which are of great significance. Our built environment encompasses land use patterns and all building spaces and elements that people construct or modify. This includes housing developments, schools, health centers, workplaces, urban parks, and sport and recreation areas. This urban environment can negatively or positively affect our physical activities. Urban sprawl and large shopping centers located at the outskirts of our cities increase car use and reduce opportunities for active lifestyle (walk or bicycle use when going shopping). Poor air quality might be also a serious barrier for physical activity, while a natural environment within easy access of a residential site might significantly influence participation in sports. Living in a neighborhood with recreation grounds may lower one's risk of depression and other health problems. Naturally, many factors can affect one's health and risk of disease, including age, family medical history, weight, and everyday lifestyle. However, the results of recent studies proved that the more green space people had within a 1-km radius of their residence, the less likely they were to have be diagnosed with many common health problems (asthma, breathing problems, diabetes, intestinal complaints, and neck and back problems). This study suggests that spending more time at local green areas (jogging, playing ball with others, walking a dog, watching birds with friends, etc.) may play a significant role in improving health state. Researchers from the Netherlands Organisation for Scientific Research found that depression affects as many as 32 out of 1,000 people in areas with only $10 \%$ green space. This dropped to 24 out of 1,000 people in areas with $90 \%$ green space (Maas, 2009). Therefore, open spaces at housing estates, such as a green space with facilities for rest, entertainment or physical exercise, should be provided to help all residents practice sports as an everyday pastime. Outdoor recreation areas should be an obligatory component of existing and planned housing estates in view of their crucial importance to healthy lifestyle, thus upgrading the quality of life. It is to be underlined that the increased mental strain of urban community living makes it imperative to provide recreation grounds with good facilities, as active recreation and sports are the most effective for eliminating fatigue of the nervous system. Moreover, green space, urban parks, and sport and recreation facilities can contribute to social cohesion, increase a sense of social identity, and enhance people's perception of neighborhoods. Providing opportunities for safe outdoor recreation may enable better social networks to be built, which is especially important for children, older residents, and the disabled. Without doubt, outdoor recreation grounds that are adequately equipped and conveniently located to the residential site should be the principal factor in determining the functional program of housing estates. Shaping good conditions for everyday active recreation will stimulate the daily routine of local community members and be a counterbalance to the negative effects of the contemporary stressful urban life (Fitzjohn, 2008; Kosiewicz, 2010; Torkildsen, 2005).

The problem of recreation grounds and relevant facilities provided there is rather complex. Besides the tough question of the necessity to reserve a sufficiently vast non-built plot for such a function and a satisfactory solution of economical issues of management (not easy in times of crisis), other matters are involved in getting the most satisfactory effect. The design and layout of such grounds is a problem that should be elaborated on not only by architects and urban planners, but also by other professionals: physicians, sociologists, psychologists, and physical education specialists (Ravenscroft, 2011; Roberts, 2010). For example, as recent changes to our pace of living and quality of life (including demands of our leisure possibilities) have been rapid, our society has also changed. We are now expecting higher standards of living filled with goods, services, and recreational activities unimaginable some decades ago. Recent social changes include a steadily increasing urban population, falling birth rates, aging populations, longevity of life, and couples who are having families later. These trends have an influence on the type and character of recreational facilities that should be provided at housing estates (Fitzjohn, 2008; Pawlikowska-Piechotka, 2011; Williams, 2003). 


\section{Research questions, materials, and methods}

The study of contemporary trends of leisure provision could be an essential spatial planning tool when contemporary housing estates functional programs are considered. Our research study was conducted on the basis of grants ds-114 and ds-144 JP UPE in Warsaw. The research was conducted in 2008-2012. It was supported by the Ministry of Science and Higher Education. Doctorate students at JP UPE were involved in field studies (spring semester of academic years: 2008-2009, 2009-2010, and 2010-2011). Our research aimed to provide information on present trends in the area of active recreation that could impinge on leisure facilities expected at urban housing estates (outdoor recreation grounds). By physical activity we understand any force exerted by muscles that results in energy expenditure. This includes walking or cycling, traditional outdoor games, gardening, or sport. This also includes deliberate exercise (both organized and informal, with special facilities or without sport / recreation amenities) (Edwards, 2006). By active living we understand a way of life that integrates physical activity into daily routine (at least 30 minutes of activity each day) (Edwards, 2006).

For our field studies (to obtain primary data and qualitative data material), selected contemporary sport and recreation grounds in Warsaw were surveyed, mainly in the northern part of the city (Bielany and Żoliborz boroughs). Our case studies were undertaken on specific themes: access to urban greens, facilities (sport and recreation grounds equipment), safety, management (maintaining, repairing, and inspecting equipment), user characteristics, popularity of sites, and comments of users on proposed renewal strategy (with users of public green space interviewed). Our research also focused on the community diversifying preferences, their expectations for outdoor recreation infrastructure and management improvements. Emphasis was also placed on disabled adults and children, the conditions that limit the use of green areas by these groups in the context of civil rights of people with disabilities, and potential technical, organization, and design improvements. We not only intended to identify desirable trends in sport and recreation ground design, but to also recognize the specific considerations for safety and the interrelationships between the changing structure of modern public urban space and the development of sport and recreation areas. Such a perspective, as we hoped, helped to explore the problem holistically and drew out a range of ideas on sustainable urban planning, with respect to health-friendly cities and with equal opportunity issues for different groups of society in mind. Research methods were multidisciplinary and related to the research objectives, which meant that several different approaches were required. The study was based on a review of the literature, collection and analysis of existing survey data, field notes, observation, and interviews. This mixed methods project comprised two forms of data collection. The primary (qualitative) data collection involved surveying selected sport and recreation grounds in Warsaw. The interview questionnaire included questions that covered a range of themes designed to elicit experience of sport and recreation ground accessibility, location, equipment, safety, and conflicts of interest (e.g., different age groups of visitors, different ways of using ground equipment, and presence of dogs). Interviews were generally mainly with adults, lasted about 25-30 minutes, and were performed in situ. All spontaneous comments from children were also recorded.

\section{New urban society members, new expectations}

The population in Polish cities has grown steadily over the decades; today as many as $61 \%$ (nearly 19 million) of Poles live in cities. Moreover, the total urban population of 18,768,473 has not reached its limit: recent demographic projections suggest that the number of Poles living in cities will exceed 20 million in 2020. The number of urban people aged 65 years and over will possibly exceed the numbers of those aged 16 years and under by 2020 (GUS, 2011). What kind of society is this? How much does today's urban society differ from previous generations? In Poland, one of the biggest changes in social behavior over the last two decades has been the general tendency for urban woman to have fewer children or to delay having children (a result of higher education and labor market rules). Another striking change is the increase in one-person households as a result of: never married men and women, an increase in divorces, and an increase in elderly 
widowed women (GUS, 2011). All these significant changes have serious implications for active recreation demands, as different age groups and different families have different tastes and expectations. For example, a new factor that should be considered by urban planners is the ageing process of the Polish population: a growing group of urban elders who have more time and higher expectations than ever before. Better health care and greater knowledge about healthy lifestyle led to demand for sport and recreation facilities provided for elders. In terms of green areas at housing estates, elder residents also expect to be provided with good facilities and wide choice of activities. Moreover, today has a new self-image of a fit, toned woman who exercises, plays sports, and is competitive. In Poland, women are interested in many activities that some decades ago were not considered "suitable and appropriate" for them. For example, women take part in the traditionally men-only sports of football, rugby, hockey, and judo. The presence of children within the resident community (however limited in size these days) also has an important influence on the type of facilities that should be provided. Overall, the mode of leisure and entertainment (and consequently the program of neighboring sport and recreation ground) is determined by many factors, such as income, age, gender, social and profession, as well as by family status and place of residence (central or suburban locations). According to recent research, most Poles living in cities prefer cycling, gardening, and swimming as favorite pastimes (Mogiła-Lisowska, 2010).

\section{The character of contemporary recreation facilities}

In the urban planning process, especially when housing units are concerned, the importance of functional zoning at early planning stages is strongly stressed. In Poland, land use planning is a process concerned with the determination of land functions, the general objectives produced according to legislation issued by parliament (Act of 7 July 1994; Act of 27 March 2005). At the heart of land use at housing estates should be the idea of zoning the land for crucial purposes: residential and health care; retail services and education; religious and transport. The zoning system should also include open space layout for active recreation. It is necessary to underline that land use planning can relate both to newly developed areas and to existing ones. While recreation needs are considered in early planning stages, it is more promising for really interesting recreation area arrangement (Pawlikowska-Piechotka, 2012; Veal, 2011). The range of possible facilities and the richness of a recreation ground program are enormous. However, housing co-operatives and managers of communal or corporate housing dwellings have, over the past decades, developed their own views on recreation grounds. It is necessary to revise it. In considering the needs and expectations of modern society, managers and local councils might be expected to make greater efforts to arrange recreation grounds. An assessment can be made on the basis of common sense (simple children facilities such as sand boxes and see-saws are always welcome), observation (which facilities are more popular than others), and special research (such as the ds-114 and ds-144 grants conducted at JP UPE in Warsaw). The character of facilities necessary for active recreation at housing estates might be classified on four basic levels:

a) recreation and leisure facilities that provide housing estate residents with possibilities of physical exercises (active recreation) without any supervision or control (playing fields, physical training equipment);

b) children playgrounds provided to ensure possibilities of active recreation and leisure (sandbox, seesaw, etc.), planned as part of greens of housing estates or in public space as parks;

c) recreation and leisure facilities for elderly and disabled (such as equipment to improve mobility), to be performed as a pastime, but supervised; provided at public parks;

d) sport and cultural event facilities applied to competitive sport and sports events; to be viewed by large numbers of spectators.

At housing estates we generally have only first two types of recreation grounds: the aforementioned a) and $b$ ). The facilities for sport and cultural events require special consideration: to accommodate vast number of spectators, once the recreation ground at housing estate is meant to offer some simple facilities, possibilities for rest and relaxation. The specially constructed facilities for elderly and disabled require the presence of specialists when people exercise (such as in Madrid El Retiro Park or Hyde Park in London). 
However, simpler facilities could be treated as a part of a recreation area for housing estates to provide truly "for all" opportunities and space without barriers. It refers both to the first and second type (a) and (b) of recreation grounds. The main idea of a housing estate recreational area is to enable everyday bodily exercise for mid-aged adults as well as children and elderly. That is why these types of facilities should be considered when a community green area is planned. Naturally, in order to ensure full utilization of sport and recreation facilities, accessibility must be a very important issue. This includes a good connection to the block of flats, no architectural barriers, the possibility for some of the gymnastic apparatus to be used by elderly or disabled, year round possibilities for exercise, and the non-commercial (free of charge) offer of services. Needless to say, all elements of a recreation area should be incorporated into natural greenery. Many scholars consider greens to be an essential component of sport and recreation grounds. It has been proven that due to its outstanding aesthetic and biological values vegetation gives special character to the whole area and protects environmental quality. Moreover trees and shrubs make it easier to subdivide the recreation area into functional zones and separate different activities (for example, children's playground and sport fields). As a neighborhood recreation ground is a 5 to10 minute walk from dwellings, there is no need for service buildings with storerooms, lockers, and public restrooms. However, a porch or canopy with sitting places and picnic tables might be an important improvement (Korzeniewski, 1989; Pawlikowska-Piechotka, 2011; Wirszyłło, 1965).

The distribution of facilities within a recreation area requires consideration of interrelationships between particular items of equipment and their effective use (Figure 2). Theoretically, the best shape is a rectangle, which allows for the safe passing from one apparatus to another, from one play field to another. However, it is not necessary to have overly geometrical planning and excessively regular shapes of zones (except the rigorous dimensions and shapes of playing fields) (Table 1). The recommended tendency in planning neighborhood recreation areas is instead freedom in arrangement of the component parts (organic linking) within the established framework of functional connections, with the natural resources of landscape - such as existing trees - consequently protected. The design values of composition should be seriously considered, as sport and recreation grounds should always be harmoniously shaped, safe, and special attention should be paid to aesthetic quality. To avoid unpleasant dog litter at neighborhood recreation grounds, specially designed "dog litter" waste bins are necessary (together with continuing community education on this matter).

Table 1. Playing fields for popular games: dimension and required space

\begin{tabular}{llll}
\hline Sports & $\begin{array}{l}\text { Pitch dimension } \\
\text { (area brutto) }\end{array}$ & $\begin{array}{l}\text { Required space } \\
\text { (area brutto) }\end{array}$ & $\begin{array}{l}\text { Number of players } \\
\text { (required space per } \\
\text { person - brutto area) }\end{array}$ \\
\hline Handball & $25 \mathrm{~m} \times 50 \mathrm{~m}$ & $1,250 \mathrm{~m}^{2}$ & 14 \\
& $(28 \mathrm{~m} \times 56 \mathrm{~m})$ & $\left(1,568 \mathrm{~m}^{2}\right)$ & $\left(112 \mathrm{~m}^{2}\right.$ per person) \\
Netball & $9 \mathrm{~m} \times 18 \mathrm{~m}$ & $162 \mathrm{~m}^{2}$ & 12 \\
& $(12 \mathrm{~m} \times 22 \mathrm{~m})$ & $\left(264 \mathrm{~m}^{2}\right)$ & $\left(23.6 \mathrm{~m}^{2}\right.$ per person) \\
Basketball & $14 \mathrm{~m} \times 26 \mathrm{~m}$ & $364 \mathrm{~m}^{2}$ & 10 \\
& $(16 \mathrm{~m} \times 28 \mathrm{~m})$ & $\left(448 \mathrm{~m}^{2}\right)$ & $\left(4.48 \mathrm{~m}^{2}\right.$ per person) \\
American bowling & & 8 \\
& $1.7 \mathrm{~m} \times 29 \mathrm{~m}$ & $300 \mathrm{~m}^{2}$ & $\left(4.5 \mathrm{~m}^{2}\right.$ per person) \\
Universally designed & $(10 \mathrm{~m} \times 36 \mathrm{~m})$ & $360 \mathrm{~m}^{2}$ & 22 \\
playing pitch & $(36 \mathrm{~m} \times 60 \mathrm{~m} \times 66 \mathrm{~m})$ & $1,800 \mathrm{~m}^{2}$ & $\left(108.8 \mathrm{~m}^{2}\right.$ per person) \\
Tennis & $23.8 \mathrm{~m} \times 11.0 \mathrm{~m}$ & $261.8 \mathrm{~m}^{2}$ & 4 \\
& $(20 \mathrm{~m} \times 40 \mathrm{~m})$ & $\left(800 \mathrm{~m}^{2}\right)$ & $\left(20 \mathrm{~m}^{2}\right.$ per person) \\
Exercise field & $(9 \mathrm{~m} \times 20 \mathrm{~m})$ & $180 \mathrm{~m}^{2}$ & 30 \\
& & & $6 \mathrm{~m}^{2}$ per person \\
\hline
\end{tabular}

Source: on the basis on field studies and technical data (Neufert, 2002).

\footnotetext{
${ }^{2}$ Though an American bowling alley may have any number of lanes, a typical one usually has 8 lanes (lane width: $0.9 \mathrm{~m})$.
} 
When planning neighborhood recreation grounds several factors must be considered: age groups, current trends and fashion, economic aspects, size of land, planning and architectural composition, and legal regulation on spatial planning and building. The basic size of the recreation ground should be calculated accordingly to the number of inhabitants (approximately: for a housing estate of 6,000 inhabitants, we need 3 hectares). As the minimum space required for one user is about $50 \mathrm{~m}^{2}, 3$ hectares is enough for 600 inhabitants to exercise at the same time (10\% of total population). The considered forms of active recreation should be of universal character, allowing all kind of games, gymnastic exercises, and summer and winter

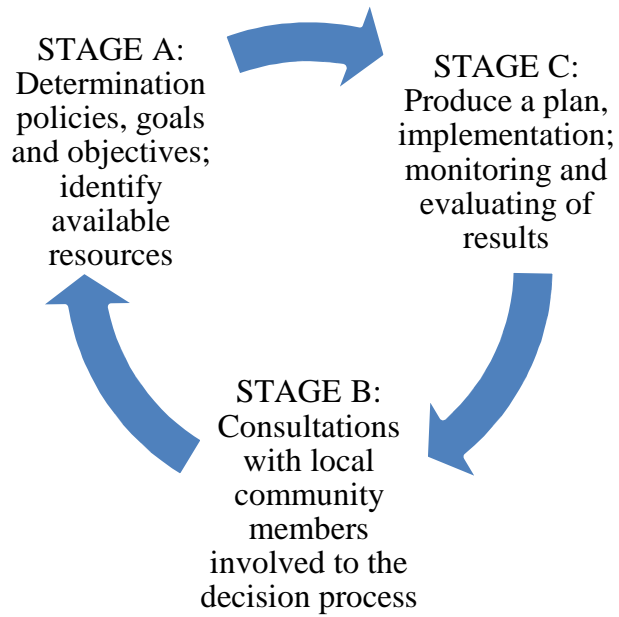

Figure 1. Proposal of a neighborhood sport and recreation grounds planning process

Source: on the basis of study ds-114 \& ds-144 JP UPE in Warsaw (2007-2012). sports to be practiced. Ideally, it should be safe and healthy, also having a pedagogical function (helping to develop and improve natural movements, mobility, motional memory, willpower, and discipline) (Table 1). The next factor in determining the functional program of a recreation ground is the local community characteristic and interest expressed in particular games and exercises. It varies in time (fashion), with age, daily occupation, and family status (Mogiła-Lisowska, 2010). That is why the possibility of the universal use of a recreation area is so important: the increased types of games and exercises users should be able to perform at the same time, the better the response will be. Another asset is the flexibility of a neighborhood sport playground according to the expectations and needs of inhabitants (Figures 1 and 2).

The easy access and attractive facilities to neighborhood recreation areas, combined with a lack of rigorous regulations, should encourage the local community to practice their favorite sports on daily basis. Sadly, mainly due to economic reasons, urban citizens are today too often deprived of proper green areas with interesting sport and recreation facilities. Unfortunately, the present trend (as observed in Warsaw) is to reduce the size and program of the neighborhood recreation areas. Frequently noticed are cases of limiting the open green space in existing or new housing estate that would enable daily active recreation (Table 2 ).

Figure 2. Plan of neighborhood sport and recreation ground (suitable for housing unit of about 3,000 inhabitants)

Source: Example of recreation ground for small size housing unit in Warsaw (area of 1.5 ha, servicing 3,000 inhabitants): 1service building, 2 - basketball pitch, 3 - netball pitch; 4 handball pitch; 5 - children's playground; 6 - eleven-story buildings; 7 - five-story buildings (on the basis of archive materials drawn by: eng. arch. A. Pawlikowska-Piechotka and eng. arch. M. Piechotka, 2012).

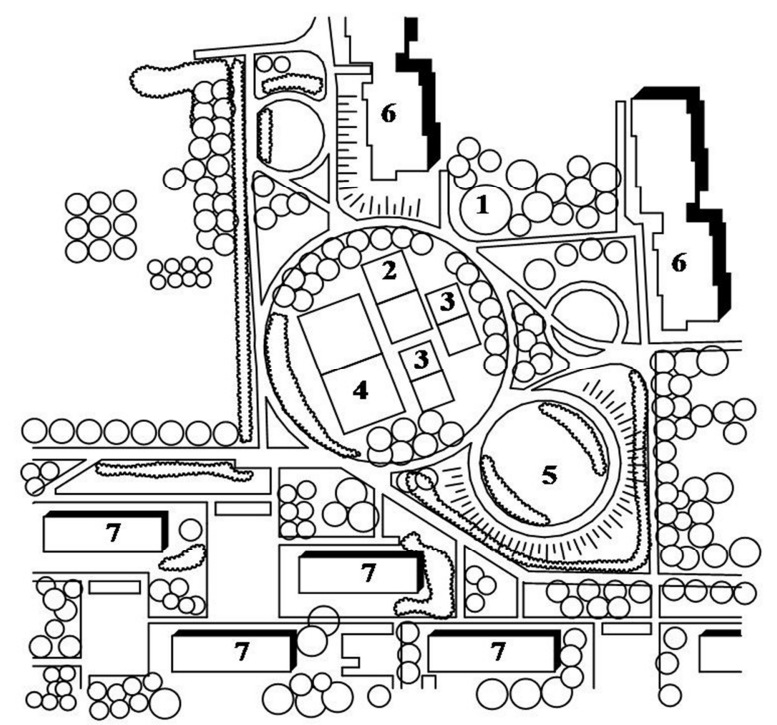

Table 2. Warsaw: changes of recreational grounds and population ratio (1990-2005)

\begin{tabular}{lllll}
\hline Year & $\mathbf{1 9 9 0}$ & $\mathbf{1 9 9 5}$ & $\mathbf{2 0 0 0}$ & $\mathbf{2 0 0 5}$ \\
\hline $\begin{array}{l}\text { Recreational } \\
\text { area (ha) }\end{array}$ & 1,855 & 1,908 & 1,760 & 1,756 \\
$\begin{array}{l}\text { Population } \\
\begin{array}{l}\text { Population and } \\
\text { recreation } \\
\text { grounds ratio }\end{array}\end{array}$ & $\begin{array}{l}1,655,700 \\
892 \text { people per } \\
\text { hectare }\end{array}$ & $\begin{array}{l}1,635,100 \\
856 \text { people per } \\
\text { hectare }\end{array}$ & $\begin{array}{l}\text { 1,672,400 } \\
950 \text { people per } \\
\text { hectare }\end{array}$ & $\begin{array}{l}\text { 966 people per } \\
\text { hectare }\end{array}$ \\
\hline
\end{tabular}

Source: On the basis of GUS Statistic Office in Warsaw (2008) (31.12.2007). 


\section{Responding to various groups needs (children and older people)}

Sufficient provision of recreation opportunities with respect to everyone as potential beneficiaries is very important. When planning outdoor recreation and sport grounds, special attention should be paid to several key population groups. Children, people with disabilities, and older people have particular needs in terms of recreation and sport. Therefore, these groups require special effort to enable them to practice regular physical activities. Unfortunately, in most Polish cities opportunities for children to be physically active have been dramatically limited. It is connected with poor road safety, dangerous traffic, and fear of criminal behavior in public space. Furthermore, the observed shrinkage of town green areas can be a serious barrier (Table 2). As a result, parents are more reluctant to let their children play outside or to go to a playground on their own. Moreover, highly exclusive sport and recreation grounds, often located far from the site of the residence, are not available for children from low-income families. This also explains why children so often drop out of sports, left with nowhere to go. Too often poorly furnished and of limited size, recreation grounds cannot compete with computer gaming and watching TV. For most children, regular outdoor recreation is perceived as fun and pleasurable; engagement in physical and sport is a very natural decision. Accordingly to experts, about one hour or more of moderate physical activity at least five days a week is highly recommended (Edwards, 2006). Unfortunately, according to recent studies only about one-third of children meet this guideline (Edwards, 2006). It is a serious problem, as everyday physical activities are essential to the healthy development of children and youth. Physical exercise not only provides physical abilities but also helps to shape social, behavioral, and mental benefits. Most scientists underline that children could achieve higher activity levels and more time spent outdoors with better access to facilities, parks, and activity programs (Edwards, 2006).

Older people are not homogenous and form diverse groups based on various preferences, levels of independence, and mobility. Although it is not easy to change one's habits and style of living, most specialists agree that it is never too late to initiate regular physical activities (Kozdroń, 2010). Even moderate exercise can make a big difference in the quality of life and well-being of older people (as being independent, actively participate in community life). Despite these facts, older people in Poland remain among the least active of all groups of our society (Mogiła-Lisowska, 2010). It is to be underlined that several key barriers are very much the same as typical for children and include: problems with accessibility, cost of sport club membership, public safety issues, road traffic, and unsafe street crossings. Other limits are issues related to ageism and a belief that sports are for the young and fit, feelings of isolation and lack of support from others, weather conditions (unpleasant very low temperatures in winter or heat waves in summer), icy and dangerous sidewalks, and fear of poor lit stairs in underground passages (PawlikowskaPiechotka, 2011, 2012).

The relationship between the provision of outdoor recreation spaces friendly to children and older people and successful promotion of regular physical activities is clear. Therefore, success in changing the lifestyles of these members of our society for ones that are more active and healthier should be associated with changes in urban planning, better education, and support from recreation specialists.

\section{Planning sport and recreation grounds for disabled (adult and children)}

It should be underlined that in Poland people with disabilities represent a large and growing segment of our population: at present, about 4,450,000 people, or about 14\% of our total population (GUS, 2012). They are often less physically active than people without disabilities. As physical activity is very important to reduce the number of secondary conditions that can result from an initial disability, we may consider this a serious problem (Conseil de l'Europe, 1992; UN WHO, 1982). Key barriers for the disabled use of outdoor recreation grounds are very similar to those listed by older people and include: difficulties with accessibility to sport and recreation grounds, cost of sport club membership, public safety issues, fear of road traffic, unsafe street crossings, ageism, isolation, lack of support from others, dangerous sidewalks, and fear of poorly lit stairs in underground passages (Pawlikowska-Piechotka, 2010, 2012). However, through changes 
in planning approach and improvements provided in sport and recreation urban areas, we may allow this group a greater participation in physical activities.

Most recreation grounds could be used by people of all abilities: for the able-bodied and disabled. For example, footpaths do not need adaptation for wheelchair use (as long as there is a suitable level access, smooth and well drained surface); table tennis can serve everybody equally. The general idea is to provide facilities and open spaces that are accessible for children and their caregivers, older people, and people with disabilities (ramps where necessary, hard surfaces, enough space to facilitate easy movement of prams and wheelchairs). To meet these requirements, footpaths should be level and smooth, firm and slip proof (loose materials such as gravel are unsuitable). If changes in levels along footpaths are unavoidable, ramps should be provided (not steeper than 1:20) with handrails to both sides of ramp. The recommended width of passages is $2 \mathrm{~m}$. If footpaths are level with some activity areas (cycle route), they should be clearly marked (with colour, surface texture contrasts). Lighting (lamps), waste bins, and seating should be provided at regular intervals along pedestrian and cyclist routes. As elderly people are sensitive to glare and sun, it is important to provide both sheltered and shaded resting places. Seats and picnic tables should be designed considering the possibility of the half sit-half stand position.

Play areas for children should be designed to permit the possible use for disabled children: free from obstacles which might exclude them, with smooth, firm and hard, slip-resistant surface, ramps (no stairs) with handrails and protective barriers, grab rails and bars to allow children to get out independently of wheelchairs. It includes as well special facilities for a children's playground, raised flower beds, sandbox, ornamented fish pond, and a list of fragrant plants recommended for a scent garden. To avoid dog litter at the playgrounds, the sites should be fenced and gated (gate with latch to be opened by person on a wheelchair). Sitting areas should be arranged under trees. The playground should be surrounded by grassy areas (picnics) (Neufert, 2002; Pawlikowska-Piechotka, 2011, 2012).

As signposting in public space is essential, especially for people with sensory disabilities, all neighborhood recreation areas should have consistent and clear information system (signposting with concise guidance, a minimum of words, and with well-known graphic symbols). For the blind and partially sighted, signs in Braille could be considered together with listening posts (audio information). The signboards should be displayed in strategic locations, permanently, well lit and also at a height readable by short people or in wheelchairs.

However, as it has to be underlined, the most obvious barriers for people with disabilities are not outdoor recreation grounds or urban park arrangements themselves, but inaccessible buildings and their surroundings. Unfortunately for many our disabled citizens, a lack of sidewalks, excessively rough surfaces, and dangerous road traffic make mobility difficult. Therefore, better access to recreation areas (wellmaintained and safe playgrounds, urban parks, and sporting areas) within walking distance from the place of residence is very important. Moreover, besides the aforementioned limits connected with a lack of or inappropriate recreation facilities, urban and architectural barriers or individual characteristics (negative attitude, lack of motivation), it is necessary to mention economic issues and poor information about free-ofcharge local possibilities of various kinds of physical activities. These issues should be also a matter of concern for local governments and housing estate managements.

\section{Conclusion}

The World Health Organization (WHO) considers everyday physical activity an essential component of all strategies that aim to address several health problems resulted from sedentary living, such as the obesity observed among children and adults (UN WHO/ Europe, 2012). It is assumed that active living and everyday sports contribute not only to individual physical and mental health but also to social cohesion and community well-being. Moreover, everyday opportunities for physical activities should not be limited to organized recreation. Individuals should find appropriate establishments not only in their residential neighborhood, also where one studies or works. The way our cities are planned or renovated might strongly 
influence our style of living, ergo increase level of our physical activity, and as a result, improve health condition. The lack or poor state of outdoor recreation space is a serious barrier to practicing favorite sports or games every day. Many people suffering negative health effects such as obesity and chronic diseases are those living in built environments deprived of open greens. Therefore, we indeed see a crucial role of local governments and urban planners responsible for creating sport and recreation grounds and the green environment that encourage physical activity.

Provision for new sport and recreation facilities has been explosive in the past two decades. In Polish cities, commercial leisure swimming pools, fitness clubs and "mega everything" are now common. But there have also been other changes, as the closure of sport football clubs, liquidation of playing fields, and changes in location and changes in use (as children's playgrounds are converted into flower beds) are sometimes very subtle and not easily noticed. For example, many older sport facilities, especially swimming pools, were closed when reaching the end of their economic lives. Naturally, changes in provision were not simply connected by economy and land use changes, but also by significant social trends, such as demography, changing recreation fashions and a rise in health consciousness. All in all, these changes have had a significant impact on the distribution of facilities, on housing estate social programs, and on the urban quality of life.

According to the previous laws of various kinds referring to town planning standards in Poland, residential units built from 1945-1990 had to establish recreation and sport grounds. The quality and maintenance of housing greens were often disputable, but by law a certain size of non-built plot had to be provided in each dwelling. In the last two decades, due to changes in regulations on building and spatial planning, newly built housing estates need not have recreation and sport facilities (Act of 7 July 1994; Act of 27 March 2003). The designer's freedom is limited to investor demands; these are connected with tough economical issues. The question is how we could launch healthy lifestyles and promote active recreation and sport for all projects when we experience a serious lack of provision for urban neighborhood recreational grounds. It is feared that without changing spatial planning and building regulations, a truly universal development of daily sport exercises and improvement of health conditions will not be possible. It is a very serious problem, as neighborhood recreation grounds, shaped in compliance with the principles presented and discussed in this paper, would not only provide ample opportunities for all kind of recreation activities, but also help to shape a better social environment, one that would allow local community interrelations to be initiated and strengthened. Moreover, the essence of community-developed approach to planning should be the recommended practice. Especially when recreation grounds are concerned, public participation in all planning process stages are important. There are two main elements in this process that should be considered:

a) the concern to increase the level of public involvement in decision-making about development of recreation areas (particularly important on a neighborhood level)

b) the concern with communal and human aspects of recreation.

However, as our research shows, up to now public participation and response to meetings and surveys on planning policies has often been minimal. Hopefully, in future people will understand more about the issues concerning their own neighborhood and will be more prepared to participate in such initiatives and open to the following issues:

1. The low level of participation in health-enhancing physical activity, which affects health and government, especially on the regional and local levels; there should be alarm about the increase of the frequency of chronic diseases, obesity, and non-active lifestyle of Polish society.

2. Along with dietary changes, physical activity and practicing sports everyday - at least 30 minutes is beneficial to health at all ages, but especially to children and teenagers. It is to be underlined that daily physical activities for seniors might make a dramatic difference to the quality of life for elder groups.

3. Moreover, active styles of living can positively contribute to the economic and social cohesion in the Polish towns, as regular participation in different outdoor recreational activities increases 
opportunities for better socialization, closer networking, and helps to built cultural identity among community members.

4. Providing sufficient outdoor recreation grounds in housing estates or their neighborhood requires the involvement and cooperation of government at all levels: national, regional, and local. Each should have a clearly defined role and commitment. But local government has an especially crucial role to play in creating the environment, which provides an opportunity for physical activities and outdoor sports.

5. While people's participation in outdoor sports depends on many factors - those shaped by built and natural environment, by social conditions, numerous personal factors - design elements of urban structure can either promote or discourage physical activities. Provision of recreation grounds, pocket gardens, community greens, and urban parks can greatly encourage people to practice outdoor physical activities. These places should be safe and friendly, without air pollution, and with high aesthetic value.

6. Disadvantaged groups, such as people with different health problems and decreased mobility, tend to be less active. Therefore, local strategies should be focused on the needs of these groups and programs that encourage more frequent participation. It is a part of a broader policy of launching special attention to equality and vulnerability.

In many Polish housing estates, opportunities for physical activity need to be created closer to where people live and treated as part of clean, safe, green, activity-friendly urban environment. They should enable the decision to live actively to be an easy one. This will help to promote active lifestyles and a habit of everyday sport practice in all groups of Polish society. However, it requires effective partnership at the local level. Finally, responsibility needs to be taken by urban planners, house managements, public health and social services, and the education and sport sectors, which should also cooperate.

All in all, as mentioned previously, the relationship between active lifestyle, health, and the quality of the built environment we live in is very complicated, as it covers a number of implications. Nevertheless, creating suitable opportunities for active outdoor recreation and sport should be a priority in sustainable and responsible urban planning, as connected with public health, a high quality of living environment, costeffectiveness, and social cohesion. The authors hope that this paper will promote awareness of the urgent need to create more urban sport and recreation grounds, inspire scientific debate, and spark commitments and action by local government.

\section{Acknowledgment}

This paper is based on our planning practice and on the grants ds-114 and ds-144 JP UPE in Warsaw (carried out in 2008-2012 and supported by the Ministry of Science and Higher Education), which were aimed to provide information on present trends in the area of urban active recreation which could impinge on leisure facilities expected at urban housing estates (outdoor recreation grounds).

\section{REFERENCES}

Act of 7 July 1994 on building (with later amendments). In Polish. Dziennik Ustaw No 15 of 1999 item 139. Warsaw: Polish Parliament.

Act of 27 March 2003 on spatial planning and organization (with later amendments). In Polish. Dziennik Ustaw No 80 of 2003, item 717. Warsaw: Polish Parliament.

Conseil de l'Europe (1992). Accessibilite: principes et lignes directrices /Accessibility: principles and guidelines/. Strasburg: Conseil de l'Europe.

Edwards, P., Tsouros, A. (2006). Promoting Physical Activity and Active Living in the Urban Environment. The Role of Local Governments. Copenhagen: WHO Regional Office Publication.

Fitzjohn, M., Tungatt, M. (2008). The Changing Nature of Sports Provision and Urban Land Use. In Leisure and the Environment (pp. 101-112). New York: Belhaven Press. 
Główny Urząd Statystyczny (2012). Powierzchnia i ludność w przekroju terytorialnym. Informacje i opracowania statystyczne /Area and Population in the Territorial Profile: Statistical Information and Elaboration/. Warsaw: GUS Central Statistic Office.

Główny Urząd Statystyczny (2011). Powierzchnia i ludność w przekroju terytorialnym. Informacje i opracowania statystyczne /Area and Population in the Territorial Profile: Statistical Information and Elaboration/. Warsaw: GUS Central Statistic Office.

Główny Urząd Statystyczny (2008). Rocznik statystyczny /Statistic Yearbook/. Warsaw: GUS Central Statistic Office.

Korzeniewski, W. (1989). Budownictwo mieszkaniowe. Poradnik projektanta /Housing: A Designer's Handout/. Warszawa: Arkady.

Kosiewicz, J. (2010). Social and Biological Context of Physical Culture and Sport. Physical Culture and Sport. Studies and Research, L, 5-31. DOI: 10.2478/v10141-010-0021-1.

Kozdroń, E. (2010). Aktywność fizyczna w profilaktyce starzenia się /Physical Activity and the Ageing Process/. In K. Klukowski (Ed.), Medycyna aktywności fizycznej z elementami psychologii i pedagogiki, tom 1 /The medicine of physical activity with the elements of psychology and pedagogics, vol. 1/ (pp.133-143). Warsaw: Akademia Wychowania Fizycznego Józefa Piłsudskiego w Warszawie.

Maas, J., Verhei, R. (2009). Morbidity is Related to a Green Living Environment. Journal of Epidemiology and Community Health, 63(12), 967- 73.

Mogiła-Lisowska, J. (2010). Rekreacyjna aktywność ruchowa Polaków - uwarunkowania i styl uczestnictwa /Active Recreation of Poles - Conditions and Style of Participation/. Studia i Monografie. Warszawa: Akademia Wychowania Fizycznego Józefa Piłsudskiego w Warszawie.

Neufert, E. (2002). Architect's Data. New York: Granada.

Pawlikowska-Piechotka, A. (2010). Turystyka i wypoczynek $w$ zabytkowych parkach Warszawy /Tourism and Recreation in Warsaw Parks/. Gdynia: Novae Res.

Pawlikowska-Piechotka, A. (2011). Przestrzeń rekreacji dziecka w mieście /Children's Recreation Space in Urban Environment/. Gdynia: Novae Res.

Pawlikowska-Piechotka, A. (2012). Europejskie tradycje rekreacji w mieście /European Traditions of Urban Recreation/. Warsaw: Akademia Wychowania Fizycznego Józefa Piłsudskiego w Warszawie.

Ravenscroft, N. (2011). Recreation Planning and Development. Reading: University of Reading Press.

Roberts, I. (2010). Leisure and Recreation. London: Heinemann.

Torkildsen, G. (2005). Leisure and Recreation Management. Glasgow: Routledge.

Vael, A.I. (2011). Leisure and Tourism Policy and Planning. London: CABI Publishing.

UN WHO (2012). A Healthy Lifestyle. Retrieved from www.who/Europe

UN WHO (1982). The World Programme of Action Concerning Disabled Persons. Geneva: UN WHO Regional Office Publishing.

Williams, S. (2003). Tourism and Recreation. London: Prentice Hall.

Wirszyłł, R. (1965). Osiedlowe parki wychowania fizycznego /Housing and Active Recreation Parks/. Zeszyt 94/1965 (seria prac własnych). Warszawa: Instytut Urbanistyki i Architektury.

AUTHOR'S ADDRESS: Anna Pawlikowska-Piechotka Josef Pilsudski University of Physical Education

34 Marymoncka str.

00-968 Warsaw

Poland

Email: anna.piechotka@gmail.com 